\title{
48-week outcomes following switch from AZT/3TC to FTC/TDF (TVD) vs. continuing on AZT/3TC: 48-week interim analysis of the RECOMB trial
}

\author{
E Ribera*1, B Clotet ${ }^{2}$, E Martínez ${ }^{3}$, V Estrada4 ${ }^{4}$ J Sanz ${ }^{5}$, J Berenguer6, R Rubio7,

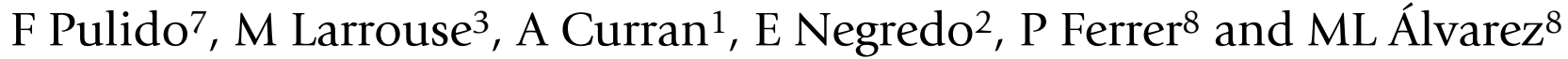

Address: ${ }^{1}$ Hospital Vall D'Hebron, Barcelona, Spain, ${ }^{2}$ Hospital Germans Trias i Pujol, Barcelona, Spain, ${ }^{3}$ Hospital Clinic i Provincial, Barcelona, Spain, ${ }^{4}$ Hospital Clínico San Carlos, Madrid, Spain, ${ }^{5}$ Hospital de La Princesa, Madrid, Spain, ${ }^{6}$ Hospital Univ Gregorio Marañón, Madrid, Spain, ${ }^{7}$ Hospital 12 de Octubre, Madrid, Spain and ${ }^{8}$ Medical Department Gilead Sciences, Madrid, Spain

* Corresponding author

from Ninth International Congress on Drug Therapy in HIV Infection

Glasgow, UK. 9-13 November 2008

Published: 10 November 2008

Journal of the International AIDS Society 2008, I I (SuppI I):P54 doi:I0.I I86/I758-2652-II-SI-P54

This abstract is available from: http://www.jiasociety.org/content/II/SI/P54

(C) 2008 Ribera et al; licensee BioMed Central Ltd.

\section{Purpose of the study}

To compare changes in total limb fat by DEXA scan assessment after switching from an AZT/3TC backbone to TVD vs. maintaining an $\mathrm{AZT} / 3 \mathrm{TC}$ regimen.

\section{Methods}

72 weeks, open label, randomised, controlled study. Virologically-suppressed HIV-infected patients $(<50 \mathrm{c} / \mathrm{mL})$ on HAART containing AZT/3TC (plus either an NNRTI or a PI) were assigned to either switch their AZT/3TC backbone to TVD or continue current AZT/3TC-containing regimen. Stratification was performed by third agent of HAART (either NNRTI or PI).

\section{Summary of results}

80 patients included (39 TVD; 41 AZT/3TC). Mean age was 44 years. Patients were predominantly male (81\%). The median CD4 cell count at baseline was higher in the TVD vs AZT/3TC arm (655 vs. $\left.504 \mathrm{cel} / \mathrm{mm}^{3} ; \mathrm{p}=0.037\right)$. (Tables 1 and 2.)

Five patients discontinued due to an adverse event before week 24; one in the TVD group (upper abdominal pain) and four in AZT/3TC group (two renal cholic, one anaemia, one lactic acidosis). Changes from BL in GFR (CG) were -11.8 for TVD and $-3.6 \mathrm{~mL} / \mathrm{min}$ for AZT/3TC.

\section{Conclusion}

Through 48 weeks, switching from a suppressive HAART regimen containing AZT/3TC to TVD, was well tolerated, maintained efficacy and led to a significant improvement in limb fat content. Additionally, haemoglobin and hematocrit significantly improved for patients switched from AZT/3TC to TVD. 
Table I: Efficacy outcomes at Week 48.

\begin{tabular}{llll}
\hline & TVD & AZT/3TC & P-value \\
\hline$\%$ of Pts with HIV RNA $<50 \mathrm{c} / \mathrm{mL}(\mathrm{M}=\mathrm{F})$ & $92 \%$ & $78 \%$ & 0.12 \\
Median CD4 count change $(\mathrm{cell} / \mathrm{mm} 3)$ & +60.5 & +9 & 0.079 \\
\hline
\end{tabular}

$M=F$ denotes missing = failure analysis. 
Table 2: Week 48 median changes from BL in limb fat, haematology and lipids

\begin{tabular}{lllllc}
\hline & TVD arm (BL) & TVD arm (Week 48 - BL) & AZT/3TC arm (BL) & AZT/3TC arm (Week 48 - BL) & P-value \\
\hline Total limb fat $(\mathrm{g})$ & 3565 & +392 & 3946 & -257 & 0.001 \\
Hb (g/dL) & 14.6 & +0.9 & 14.9 & +0.3 & 0.007 \\
Hematocrit (\%) & 42.6 & +2.7 & 42.0 & +1.0 & 0.001 \\
Total Cholesterol (mg/dL) & 187.0 & +4.5 & 189.0 & +1.0 & 0.97 \\
LDL-c (mg/dL) & 109.0 & +7.0 & 107.5 & +5.0 & 0.66 \\
HDL-c (mg/dL) & 49.0 & -2.0 & 49.5 & +2.0 & 0.29 \\
TG (mg/dL) & 110.0 & +1.5 & 120.0 & +4.0 & 0.96 \\
\hline
\end{tabular}

$\mathrm{BL}=$ baseline.

Publish with Biomed Central and every scientist can read your work free of charge

"BioMed Central will be the most significant development for disseminating the results of biomedical research in our lifetime. " Sir Paul Nurse, Cancer Research UK

Your research papers will be:

- available free of charge to the entire biomedical community

- peer reviewed and published immediately upon acceptance

- cited in PubMed and archived on PubMed Central

- yours - you keep the copyright 